Article

\title{
Investigating the Critical Factors of Professionals' BIM Adoption Behavior Based on the Theory of Planned Behavior
}

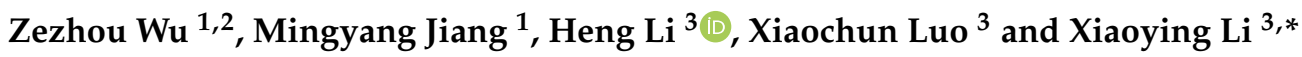 \\ 1 Sino-Australia Joint Research Center in BIM and Smart Construction, Shenzhen University, \\ Shenzhen 518000, China; wuzezhou@szu.edu.cn (Z.W.); jiangmingyang2017@email.szu.edu.cn (M.J.) \\ 2 Key Laboratory of Coastal Urban Resilient Infrastructures (MOE), Shenzhen University, \\ Shenzhen 518000, China \\ 3 Department of Building and Real Estate, The Hong Kong Polytechnic University, Hong Kong, China; \\ heng.li@polyu.edu.hk (H.L.); bsericlo@polyu.edu.hk (X.L.) \\ * Correspondence: xiaoyingk.li@connect.polyu.hk
}

Citation: Wu, Z.; Jiang, M.; Li, H.; Luo, X.; Li, X. Investigating the Critical Factors of Professionals' BIM Adoption Behavior Based on the Theory of Planned Behavior. Int. J. Environ. Res. Public Health 2021, 18, 3022. https://doi.org/10.3390/ ijerph18063022

Academic Editor: Paul B. Tchounwou

Received: 21 January 2021

Accepted: 9 March 2021

Published: 15 March 2021

Publisher's Note: MDPI stays neutral with regard to jurisdictional claims in published maps and institutional affiliations.

Copyright: (c) 2021 by the authors. Licensee MDPI, Basel, Switzerland. This article is an open access article distributed under the terms and conditions of the Creative Commons Attribution (CC BY) license (https:/ / creativecommons.org/licenses/by/ $4.0 /)$.

\begin{abstract}
In recent years, building information modeling (BIM) has been receiving growing interest from the construction industry of China. Nevertheless, although BIM has many foreseeable advantages, many studies claimed that these advantages have not been sufficiently achieved in practice at the current stage. In this circumstance, it is interesting to investigate what really drives the adoption of BIM. Based on Ajzen's theory of planned behavior (TPB), a hypothetical model which involves nine latent variables is initially established. Then, a questionnaire is designed and distributed to the construction professionals in the Chinese context. After reliability and validity analysis, the goodness-of-fit of the initial model and the related theoretical assumptions are tested through structural equation modeling (SEM). Based on the modification indicators, a modified model is finally derived. Results show that economic viability and governmental supervision are the most critical factors that influence construction professionals' BIM adoption behavior in China, sharing weights of 0.37 and 0.34 , respectively, whereas other factors play limited roles in this regard. The research findings revealed from this study can provide insightful references for countries that intend to promote BIM adoption in a similar circumstance.
\end{abstract}

Keywords: building information modeling (BIM); theory of planned behavior; BIM adoption; critical factors; China

\section{Introduction}

In recent years, informatization has been received substantial emphasis in the construction industry [1-6]. Jung et al. [7] stated that information is a critical resource in a construction project, facilitating not only effective project management, but also automation in engineering and construction. Furthermore, Lu et al. [8] argued that a particular building could be viewed as a cluster of information, and information management is critical in the process of construction project management. Nowadays, lean construction and information technologies have been used in different kinds of projects [9-12]. Under this background, building information modeling (BIM), which is regarded as a revolutionary technology for conducting effective information management during the lifecycle of a construction project, has gained growing interest from both academia and industry.

Currently, there are various definitions of BIM. For example, the National Institute of Building Sciences (NIBS) of the United States specifies that BIM is a business process for generating and leveraging building data to design, construct and operate the building during its lifecycle [13]. According to the National Building Specification (NBS) of the United Kingdom, BIM is regarded as a process for creating and managing information on a construction project across the project lifecycle [14]. Though BIM has been given different literal definitions by different countries and organizations, it is widely regarded 
as an effective technology for construction management. Currently, the implementation of BIM has become an emerging trend in the construction industry [15-20]. The potentials of BIM implementation and its benefits have been studied in existing literature, as shown in Table 1.

Table 1. Potential implementations and benefits of building information modeling (BIM).

\begin{tabular}{ccc}
\hline Category & Item & Reference \\
\hline & Cost management & {$[21,22]$} \\
& Facility management & {$[23-26]$} \\
Safety management & {$[27]$} \\
& Green building development & {$[28-32]$} \\
Potential implementation & Carbon emissions calculation & {$[33-35]$} \\
& Life cycle energy efficiency & {$[36]$} \\
& Prefabrication & {$[37-40]$} \\
& Lean construction & {$[41,42]$} \\
& Risk management & {$[43-45]$} \\
& Energy retrofitting & {$[46]$} \\
& Noise mitigation & {$[47]$} \\
& Optimizing design solutions & {$[48-50]$} \\
Enhancing visualization & {$[51-53]$} \\
Benefit & Improving teamwork & {$[54,55]$} \\
& Increasing productivity & {$[24,56,57]$} \\
& Saving time and expense & {$[58-60]$} \\
& Reducing waste & {$[61-63]$} \\
& Lifecycle management & {$[54,64,65]$} \\
\hline
\end{tabular}

However, in practice, despite these "theoretical" advantages, barriers and limitations were also observed during the practical BIM implementation [66-71]. In the technical aspect, Enshassi et al. [72] claimed that the data exchange and validation had not been thoroughly investigated. Venugopal et al. [73] suggested a modular and logical framework based on the formal specification of industry foundation classes (IFC) concepts should be developed. In addition, Lee et al. [74] revealed that the mechanism of data exchange standards still faces many challenges. In the non-technical aspect, Abd Jamil and Fathi [75] argued that BIM faces legal and contractual issues during its implementation. Raouf and Al-Ghamdi [76] reviewed BIM implementation in green buildings and found that high upfront costs and delays, design complexities and documentation requirements, superior performance enhancement requirements, and skewness towards environmental sustainability were the four major obstacles. Furthermore, Teng et al. [77] and Yu et al. [78] stated that the unbalanced profit distribution among stakeholders may hinder the active implementation of BIM.

From the above literature review, it can be seen that, as an innovative technology to provide lifecycle management throughout the complex construction process, BIM has shown great potential of solving the problems in the traditional architectural, engineering, and construction (AEC) industry. However, the advantages have not been sufficiently achieved in practice. In this circumstance, it is interesting to investigate what really drives the adoption of BIM.

In recent years, a growing number of studies have been conducted to identify the BIM adoption factors to promote BIM application in real practice $[79,80]$. Through the combination of the Collaborative BIM Decision Framework and a Focused Group Interviews analysis, $\mathrm{Gu}$ and London [69] have divided the driving factors of BIM adoption in the AEC industry into two parts (i.e., the requirement of technical tool functional and issues of non-technical strategies). Using content analysis, Mohammad et al. [81] have systematically investigated the adoption factors of BIM from the previous studies and summarized 24 most frequent variables. A five-step empirical approach has been established to understand the critical success factors (CSF) of BIM adoption at a corporate level. This study found that the "support from top management" and "functionality" of BIM tools are 
the two most significant factors for BIM adoption among total 58 CSFs [82]. More recently, Ullah et al. [83] also implemented the Technology Organization and Environment framework to investigate and classify the factors that affect BIM adoption in a contemporary public authority from the literature. However, scant research has been provided to characterize the critical factors of BIM adoption behavior from the perspective of the Theory of Planned Behavior (TPB). In this theory, three main variables, such as attitude, subjective norm, and perceived behavioral control, are regarded to determine the intention of performing behavior. It is suitable to act as a basic theoretical framework by combing other external affecting factors, and it has been widely used to explore the innovation adoption behavior in other domains $[84,85]$. The remainder of this paper is organized as follows. Firstly, an initial theoretical model and eight research hypotheses are proposed based on the summary of existing studies. This is followed by presenting the research methodology employed in this study. Subsequently, structural equation modeling is conducted to identify the drivers of BIM adoption in China and corresponding discussions are presented. This paper ends with a conclusion section.

\section{Research Hypotheses}

Individuals' behavioral intentions may influence successful BIM implementation. $\mathrm{Xu}$ et al. [86] tested individuals' BIM adoption behavior from three dimensions (i.e., technology dimension, organizational dimension, and attitude dimension), arguing that the attitude dimension could indirectly and positively affect the actual use of BIM by enhancing their interest in learning BIM technology. Howard et al. [87] investigated 84 industry stakeholders from the United Kingdom and found that the attitudes and intentions have direct and positive influences on the individuals' adoption of BIM. Jin et al. [88] also claimed that practitioners' perceptions towards BIM could affect its adoption. In this study, the TPB was selected as the basis for measuring intentions. Three variables, such as attitude towards behavior, subjective norm, and perceived behavioral control, are regarded as having direct positive effects on behavioral intentions. Thus, the following hypotheses are proposed.

Hypotheses 1 (H1). Attitude towards behavior $(A B)$ has a direct positive effect on behavioral intention (BI).

Hypotheses 2 (H2). Social norm (SN) has a direct positive effect on behavioral intention (BI).

Hypotheses 3 (H3). Perceived behavioral control (PBC) has a direct positive effect on behavioral intention (BI).

Hypotheses 4 (H4). Behavioral intention (BI) has a direct positive effect on BIM adoption behavior (B).

Technical feasibility is widely considered as an essential factor that affects the application of BIM in the construction industry. Ding et al. [89] found that technical defects and BIM capability are the key factors that hinder the architects' implementation of BIM. To achieve four-dimensional BIM, Lopez et al. [90] reviewed various technical issues concerning the usability of achieving four-dimensional BIM. Ghaffarianhoseini et al. [91] further claimed that the definitive benefits of BIM had not been adequately capitalized upon due to technical issues. Zou et al. [92] also argued that existing technical limitations (e.g., incompatibility with partners) may cause risks during BIM implementation. Therefore, the following hypothesis is proposed.

Hypotheses 5 (H5). Technical feasibility (TF) has a direct positive effect on BIM adoption behavior (B).

Economic viability may be a significant factor in adopting BIM technology. Cao et al. [93] examined the motives of BIM implementation, revealing that economic motives are significantly associated with the level of BIM adoption. Liao and Teo [94] specified advantages and financial support is a critical success factor of BIM implementation in Singapore. In another study conducted by Cao et al. [48], the importance of economic viability was further confirmed. Lee et al. [95] analyzed the economic feasibility 
of implementing a structural building information modeling (S-BIM) on high-rise building structures. Saieg, Sotelino, Nascimento and Caiado [41] also discussed the economic aspect of adopting BIM in lean construction. Therefore, the following hypothesis is proposed.

Hypotheses 6 (H6). Economic viability (EV) has a direct positive effect on BIM adoption behavior (B).

The industrial environment may influence the adoption of BIM because coordinating various stakeholders of a project is the main advantage of BIM technology. Porwal and Hewage [96] indicated that a large proportion of clients from the public sector are afraid of using BIM in their projects because they think the market is not ready for BIM. Sacks et al. [97] reviewed fifteen BIM guidelines, and standard and protocol documents and found missing aspects in some of these documents. Papadonikolaki and Wamelink [98] argued that the inter- and intra-organizational conditions are important for integrating BIM with the supply chain. Recent research conducted by Abd Jamil and Fathi [75] stated that there are still many contractual challenges to be solved for BIM-based construction projects. Therefore, the following hypothesis is proposed.

Hypotheses 7 (H7). Industrial environment (IE) has a direct positive effect on BIM adoption behavior (B).

Governmental supervision could affect stakeholders' adoption of BIM because regulations and policies can determine an organization's actual behavior. Cheng and $\mathrm{Lu}$ [99] examined the efforts made by public sectors and argued that the public sector plays a significant role in promoting BIM in the AEC industry. Chang et al. [100] even suggested that the government can mandatorily require the compulsory adoption of BIM in public projects. In addition, as the intellectual property rights (IPR) in BIM projects is of great concern [101], it is necessary for the government to make relevant regulations to protect different stakeholders' intellectual property as well as other benefits. Therefore, the following hypothesis is proposed.

Hypotheses 8 (H8). Governmental supervision (GS) has a direct positive effect on BIM adoption behavior (B).

Based on the proposed hypotheses, a preliminary theoretical model was developed, as shown in Figure 1.

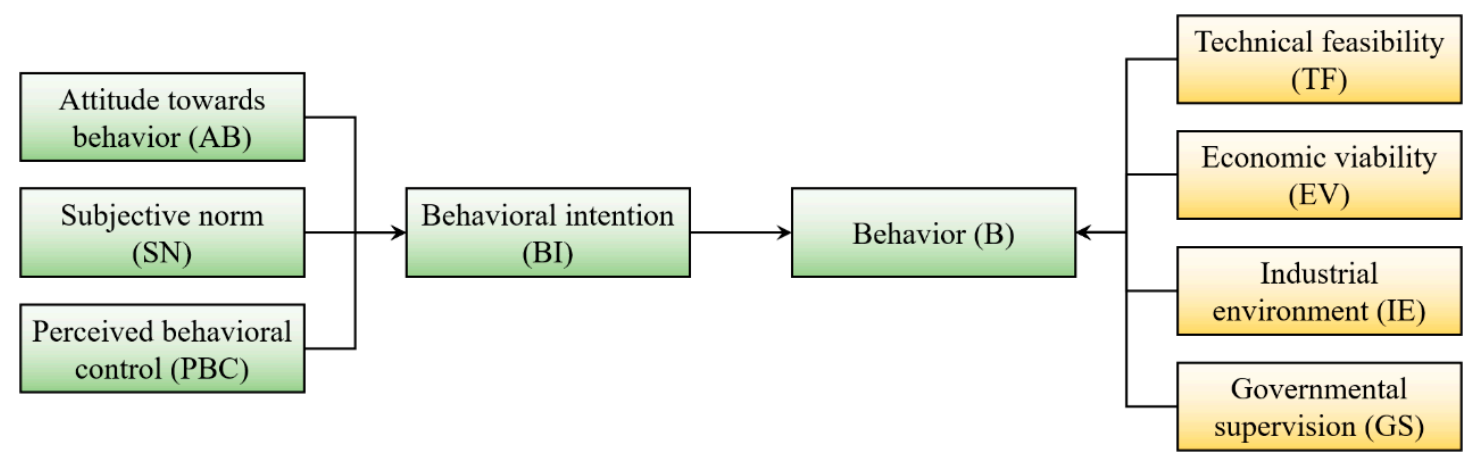

Figure 1. The preliminary theoretical model.

\section{Research Methodology}

In this study, a questionnaire was designed to investigate construction professionals' BIM adoption behavior and the affecting factors. Three sections were involved in the questionnaire. The first section investigated the background information of the respondents, including the working category, gender, education level, the number of projects participated in, etc. The second section presented the measurement scales for the nine latent variables, as shown in Table 2 . The questions used for constituting the measurement scales were initially designed according to the basic guidelines of TPB (i.e., $\mathrm{AB}, \mathrm{SN}, \mathrm{PBC}$, and $\mathrm{B}$ ) and the items identified from existing literature (including TF, EV, IE, and GS). A five-point Likert scale 
was employed, ranging from " 1 " (strongly disagree) to " 5 " (strongly agree). In the third section, an open question, namely, "please provide any comments on this questionnaire", was proposed to invite the respondents to provide their opinions. Then, three interviews with two experienced professionals and one scholar whose research interest is in this field were conducted to improve the questionnaire.

Table 2. Measurement scales in the formal questionnaire.

\begin{tabular}{|c|c|c|}
\hline Latent Variable & Measurement Item & Measurement Scale \\
\hline \multirow{5}{*}{$\begin{array}{l}\text { Attitude towards } \\
\text { behavior (AB) }\end{array}$} & AB1 & I think work efficiency can be improved by using BIM. \\
\hline & AB2 & I think construction period can be shorten by using BIM. \\
\hline & AB3 & I think project life cycle cost can be reduced by using BIM. \\
\hline & $\mathrm{AB} 4$ & I think the quality of the project can improved by using BIM. \\
\hline & AB5 & I think the image of the project can enhanced by using BIM. \\
\hline \multirow{5}{*}{$\begin{array}{l}\text { Subjective norm } \\
\text { (SN) }\end{array}$} & SN1 & My superior thinks that mastering BIM is helpful to my potential career development. \\
\hline & SN2 & My colleagues could approve me better if I am skilled at using BIM. \\
\hline & SN3 & My family supports me to use BIM in my project. \\
\hline & SN4 & The developer expects me use BIM in my project. \\
\hline & SN5 & The local government encourages me to use BIM in my project. \\
\hline \multirow{5}{*}{$\begin{array}{c}\text { Perceived } \\
\text { behavioral control } \\
\text { (PBC) }\end{array}$} & PBC1 & I have enough opportunities to use BIM in my project. \\
\hline & PBC2 & I can get enough support to use BIM in my project. \\
\hline & PBC3 & I have enough time to use BIM in my project. \\
\hline & $\mathrm{PBC} 4$ & I have enough experience to use BIM in my project. \\
\hline & PBC5 & I have adequate equipment and software to use BIM in my project. \\
\hline \multirow{5}{*}{$\begin{array}{c}\text { Behavioral } \\
\text { intention (BI) }\end{array}$} & BI1 & I am willing to use BIM technology to demonstrate the project. \\
\hline & BI2 & I am willing to use BIM technology for design optimization during the project design phase. \\
\hline & $\mathrm{BI} 3$ & I am willing to use BIM technology for project management in the construction process. \\
\hline & BI4 & I am willing to learn and to use new applications of BIM technology. \\
\hline & BI5 & I am willing to participate in BIM training. \\
\hline \multirow{5}{*}{$\begin{array}{l}\text { Technical feasibility } \\
\text { (TF) }\end{array}$} & TF1 & Data are compatible amongst different existing BIM software. \\
\hline & TF2 & The localized BIM software has been developed in China. \\
\hline & TF3 & There have been reliable platforms for BIM data exchange. \\
\hline & TF4 & The existing BIM software has good potential for function extension. \\
\hline & TF5 & Technical support can be received in the process of using BIM. \\
\hline \multirow{5}{*}{$\begin{array}{l}\text { Economic viability } \\
\text { (EV) }\end{array}$} & EV1 & Enterprise can receive satisfactory returns from using BIM. \\
\hline & EV2 & Enterprise has sufficient funding for purchasing BIM related equipment and software. \\
\hline & EV3 & Enterprise has sufficient funding for BIM related consultancy. \\
\hline & EV4 & Enterprise has sufficient funding for training BIM employees. \\
\hline & EV5 & Government has attractive incentives for promoting BIM adoption. \\
\hline \multirow{5}{*}{$\begin{array}{c}\text { Industrial } \\
\text { environment (IE) }\end{array}$} & IE1 & There is a generic BIM standard in the industry. \\
\hline & IE2 & There is a generic BIM contract template in the industry. \\
\hline & IE3 & There are good communications between different project stakeholders. \\
\hline & IE4 & The construction professionals are willing to learn and to use BIM. \\
\hline & IE5 & There are sufficient successful BIM practices in the industry. \\
\hline \multirow{4}{*}{$\begin{array}{l}\text { Governmental } \\
\text { supervision (GS) }\end{array}$} & GS1 & There have been regulations for protecting BIM related intellectual property rights. \\
\hline & GS2 & There have been regulations for protecting the benefits of different stakeholders in a BIM projec \\
\hline & GS3 & There have been disputation resolution mechanisms for BIM projects. \\
\hline & GS4 & There has been a specific government department to supervise BIM implementation in projects. \\
\hline \multirow{5}{*}{ Behavior (B) } & B1 & I use BIM to improve work efficiency in the project. \\
\hline & B2 & I use BIM to optimize design in the project. \\
\hline & B3 & I use BIM for cross-disciplinary work coordination in the project. \\
\hline & B4 & I use BIM to demonstrate the project. \\
\hline & B5 & I have participated in BIM related workshop or training. \\
\hline
\end{tabular}

The questionnaires were collected by two means. The first way was distributing the questionnaire in BIM-related professional forums. Nevertheless, the collected responses were very limited, only 47 responses were collected. In order to collect more responses, the questionnaires were then sent to construction professionals via email. The "snowball sampling" strategy was adopted by inviting respondents to hand out the questionnaire to their colleagues. This strategy was adopted because it could improve the efficiency of obtaining a relatively large number of responses [102,103]. A total of 244 responses were collected from these two methods. Subsequently, a filtering process was conducted to 
screen invalid questionnaires. After the filtering process, 206 valid responses were left for further analysis, representing $84.4 \%$ of the total responses. Structural equation modeling (SEM) was used as the main technique for the analysis. SEM was selected because it is a recognized method for testing hypotheses with empirical data [104]. Confirmatory factor analysis was conducted to test the validity of the measurement models and path analysis was employed to test the goodness-of-fit of the proposed model. After obtaining the optimized model, the significant influencing factors and corresponding regression weights can be determined. Discussions were further made by interviews with three experienced professionals.

\section{Results}

\subsection{Descriptive Statistics}

The descriptive statistics of the 206 respondents were analyzed using SPSS, as shown in Figure 2. From Figure 2, it can be seen that the respondents were mainly from the developer, contractor, and research institution, representing $85.9 \%$ in total. In addition, most of the respondents had relatively less working experience, a total of $87.9 \%$ of the respondents had working experiences less than 10 years. More than $64 \%$ of the respondents had a bachelor's degree and $35.4 \%$ of the respondents had a master's degree or above. Similar to the short working period, the number of participated projects was relatively limited, more than $90 \%$ of the respondents participated in less than 10 projects.

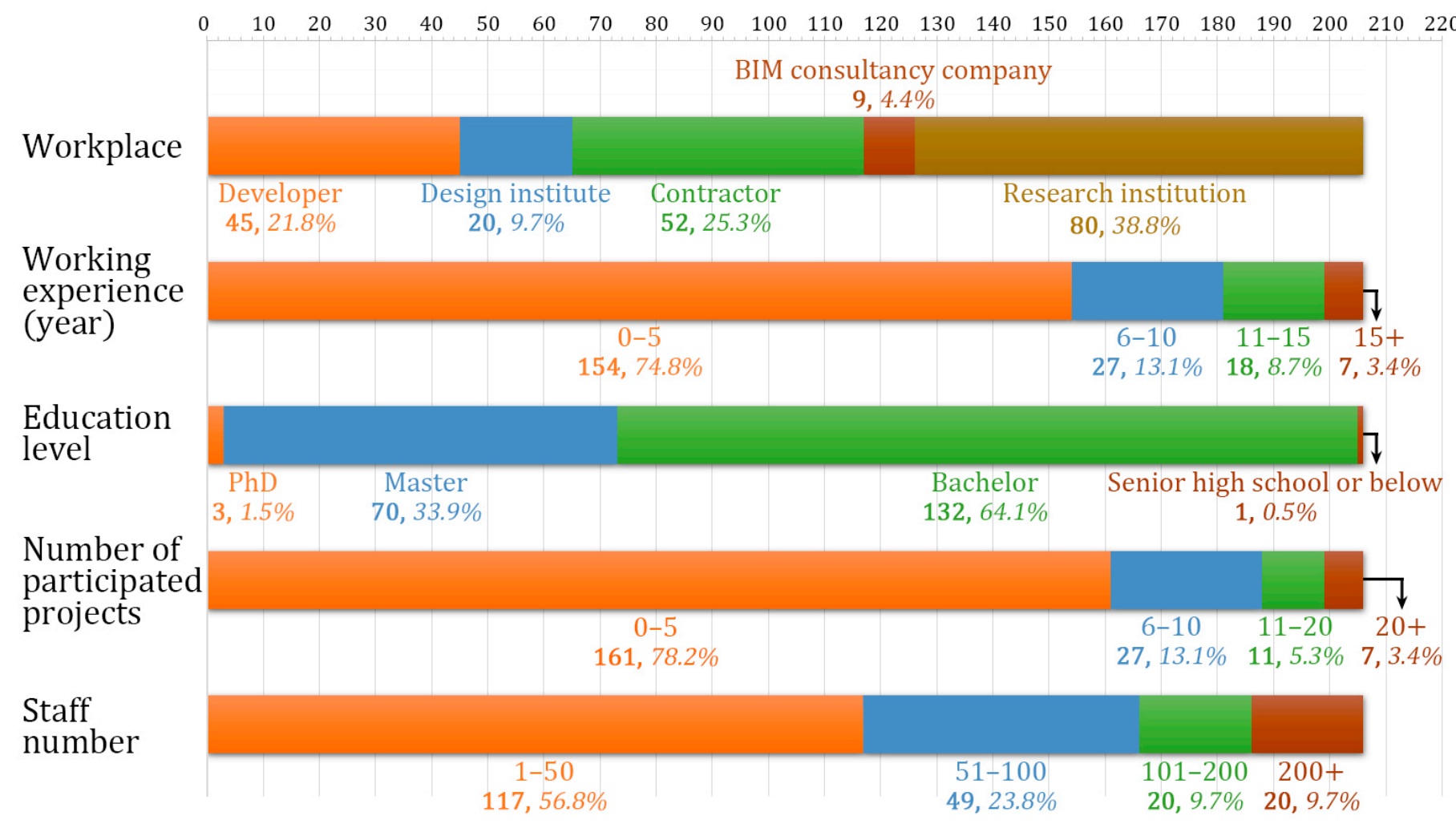

Figure 2. Stacked bar charts of respondents' personal information.

\subsection{Reliability and Validity Analysis}

Reliability analysis was conducted to test the consistency of the measurement items. Cronbach's $\alpha$ coefficient was checked for the measurement scales of each latent variable and the whole questionnaire. The value for the Cronbach's $\alpha$ coefficient ranges from 0 to 1 , the reliability of the measurement scales is considered to be high if the $\alpha$ value is greater than 0.8. In this study, the Cronbach's $\alpha$ coefficients of the latent variables of AB, SN, PBC, BI, TF, EV, IE, GS, and B were 0.901, 0.896, 0.927, 0.925, 0.896, 0.899, 0.894, 0.940, 
and 0.932 , respectively, as shown in Table 3 . In addition, the reliability coefficient of the whole questionnaire was 0.906 , indicating that the reliability of the questionnaire is good and can be further tested for validity.

Table 3. Reliability and validity analysis.

\begin{tabular}{|c|c|c|c|c|c|c|c|}
\hline \multirow{2}{*}{$\begin{array}{c}\text { Latent } \\
\text { Variables }\end{array}$} & \multirow{2}{*}{ Items } & \multirow{2}{*}{$\begin{array}{c}\text { Factor } \\
\text { Loadings }\end{array}$} & \multirow{2}{*}{$\begin{array}{c}\text { Cronbach's } \\
\text { Alpha }\end{array}$} & \multirow{2}{*}{$\begin{array}{c}\text { KMO } \\
\text { Measure }\end{array}$} & \multicolumn{3}{|c|}{ Bartlett's Test of Sphericity } \\
\hline & & & & & Chi-Square & df & Sig. \\
\hline \multirow{5}{*}{$\mathrm{AB}$} & AB1 & 0.853 & \multirow{5}{*}{0.901} & \multirow{5}{*}{0.875} & \multirow{5}{*}{606.650} & \multirow{5}{*}{10} & \multirow{5}{*}{0.000} \\
\hline & AB2 & 0.864 & & & & & \\
\hline & AB3 & 0.861 & & & & & \\
\hline & AB4 & 0.861 & & & & & \\
\hline & AB5 & 0.794 & & & & & \\
\hline \multirow{5}{*}{$\mathrm{SN}$} & SN1 & 0.886 & \multirow{5}{*}{0.896} & \multirow{5}{*}{0.818} & \multirow{5}{*}{665.012} & \multirow{5}{*}{10} & \multirow{5}{*}{0.000} \\
\hline & SN2 & 0.897 & & & & & \\
\hline & SN3 & 0.840 & & & & & \\
\hline & SN4 & 0.790 & & & & & \\
\hline & SN5 & 0.787 & & & & & \\
\hline \multirow{5}{*}{ PBC } & $\mathrm{PBC} 1$ & 0.886 & \multirow{5}{*}{0.927} & \multirow{5}{*}{0.878} & \multirow{5}{*}{806.143} & & \\
\hline & PBC2 & 0.906 & & & & & \\
\hline & РBC3 & 0.901 & & & & 10 & 0.000 \\
\hline & $\mathrm{PBC} 4$ & 0.843 & & & & & \\
\hline & PBC5 & 0.864 & & & & & \\
\hline & BI1 & 0.865 & & & & & \\
\hline & $\mathrm{BI} 2$ & 0.900 & & & & & \\
\hline $\mathrm{BI}$ & BI3 & 0.857 & 0.925 & 0.893 & 762.501 & 10 & 0.000 \\
\hline & BI4 & 0.902 & & & & & \\
\hline & BI5 & 0.865 & & & & & \\
\hline & TF1 & 0.807 & & & & & \\
\hline & TF2 & 0.830 & & & & & \\
\hline $\mathrm{TF}$ & TF3 & 0.914 & 0.896 & 0.870 & 600.738 & 10 & 0.000 \\
\hline & TF4 & 0.834 & & & & & \\
\hline & TF5 & 0.819 & & & & & \\
\hline & EV1 & 0.764 & & & & & \\
\hline & EV2 & 0.894 & & & & & \\
\hline EV & EV3 & 0.878 & 0.899 & 0.853 & 648.717 & 10 & 0.000 \\
\hline & EV4 & 0.889 & & & & & \\
\hline & EV5 & 0.793 & & & & & \\
\hline & IE1 & 0.876 & & & & & \\
\hline & IE2 & 0.874 & & & & & \\
\hline IE & IE3 & 0.858 & 0.894 & 0.797 & 665.143 & 10 & 0.000 \\
\hline & IE4 & 0.762 & & & & & \\
\hline & IE5 & 0.817 & & & & & \\
\hline & GS1 & 0.924 & & & & & \\
\hline & GS2 & 0.943 & & & & & \\
\hline GS & GS3 & 0.934 & 0.940 & 0.854 & 758.238 & 6 & 0.000 \\
\hline & GS4 & 0.881 & & & & & \\
\hline & B1 & 0.922 & & & & & \\
\hline & B2 & 0.923 & & & & & \\
\hline B & B3 & 0.916 & 0.932 & 0.883 & 923.902 & 10 & 0.000 \\
\hline & B4 & 0.919 & & & & & \\
\hline & B5 & 0.743 & & & & & \\
\hline
\end{tabular}

Factor analysis was employed to test the validity. From Table 3, it can be seen that all Kaiser-Meyer-Olkin (KMO) values exceeded the recommended good level of 0.7, and all Bartlett test of sphericity in the questionnaire maintained at the level of 0.05 . In addition, 
all the factor loadings were between 0.743 and 0.943 , exceeding the acceptable level of 0.5 . The results indicate that all latent variables passed the validity test and can be analyzed in the next step of the structural equation model.

\subsection{Structural Equation Modeling}

\subsubsection{Establishing the Initial Model}

According to the preliminary theoretical model proposed in Figure 1, an initial structural equation model was established by using AMOS 24.0, as shown in Figure 3. In the initial model, there are 9 latent variables and 44 observed variables. As there may be calculation errors in the data fitting process, a total of 44 error terms of observation variables and 2 error terms of latent variables were set in the model, which are numbered e1-e44 and u1-u2. The number of distinct sample moments was 990 and the number of distinct parameters to be estimated was 123. Therefore, the degree of freedom of the default model was 867 , which means the model is identifiable. As all of the factor loadings were higher than 0.5 , no observed variable needs to be deleted.

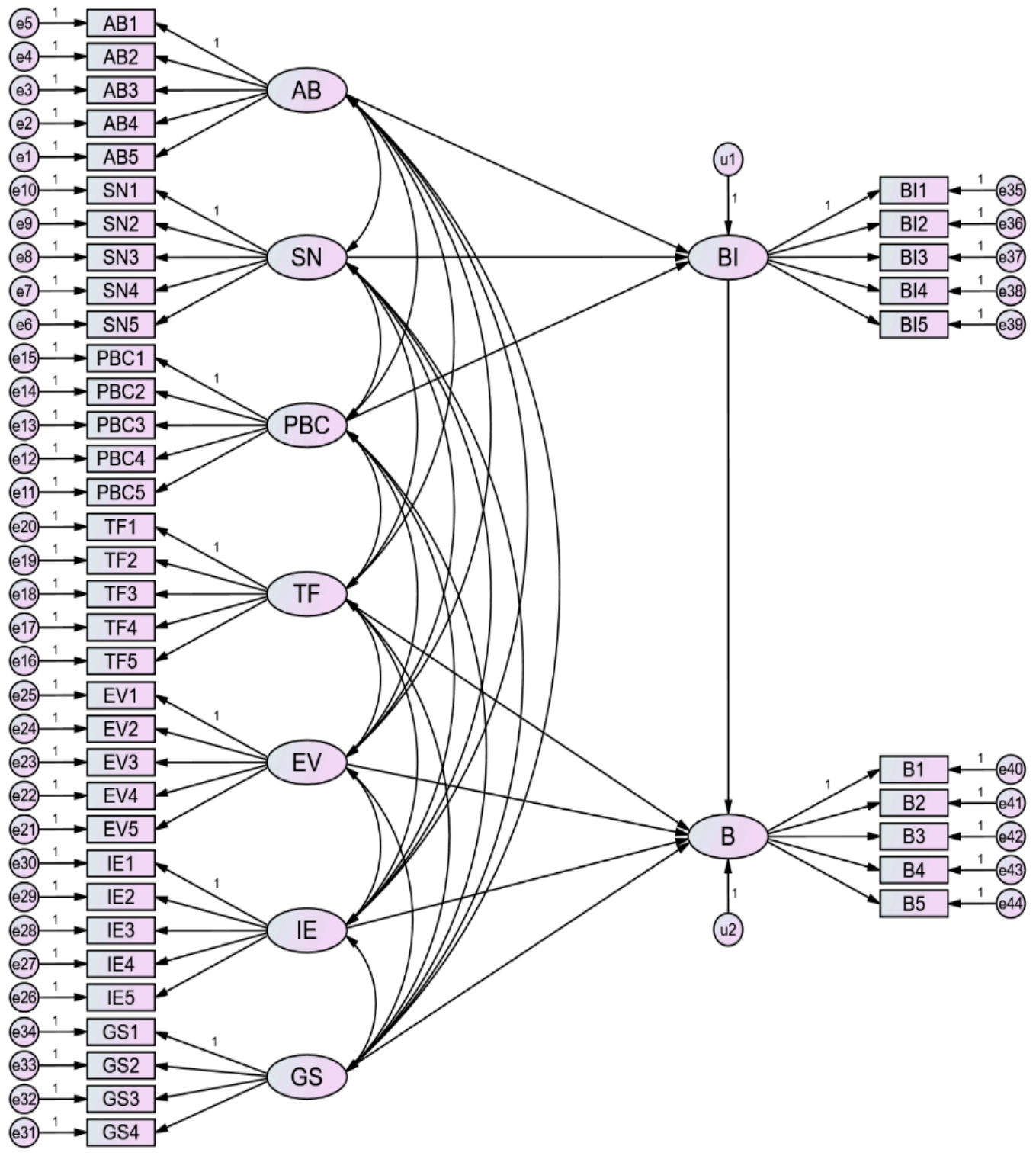

Figure 3. The initial structural equation model. 


\subsubsection{Model Fitting of the Initial Model}

Considering that the model in this paper has a multivariate estimation program of 9 latent variables and 44 observation variables, the skewness and kurtosis of each item of the scale are less than 2 , and the sample data conform to normal distribution. Thus, the maximum likelihood method was selected for model estimation. The path coefficient of the initial model is shown in Table 4. From Table 4, it can be seen that several paths existed with insignificant $p$-values.

Table 4. Path Coefficient of the initial model.

\begin{tabular}{|c|c|c|c|c|}
\hline Model Path & Estimate & S.E. & C.R. & $p$ \\
\hline $\mathrm{BI} \leftarrow \mathrm{AB}$ & 0.340 & 0.091 & 3.733 & $* * *$ \\
\hline $\mathrm{BI} \leftarrow \mathrm{SN}$ & 0.299 & 0.087 & 3.449 & $* * *$ \\
\hline $\mathrm{BI} \leftarrow \mathrm{PBC}$ & 0.061 & 0.055 & 1.116 & 0.264 \\
\hline $\mathrm{B} \leftarrow \mathrm{TF}$ & 0.037 & 0.195 & 0.189 & 0.850 \\
\hline $\mathrm{B} \leftarrow \mathrm{EV}$ & 0.765 & 0.232 & 3.301 & $* * *$ \\
\hline $\mathrm{B} \leftarrow \mathrm{IE}$ & 0.086 & 0.214 & 0.403 & 0.687 \\
\hline $\mathrm{B} \leftarrow \mathrm{GS}$ & 0.336 & 0.160 & 2.099 & 0.036 \\
\hline $\mathrm{B} \leftarrow \mathrm{BI}$ & 0.200 & 0.126 & 1.580 & 0.114 \\
\hline $\mathrm{AB} 5 \leftarrow \mathrm{AB}$ & 1.064 & 0.090 & 11.867 & $* * *$ \\
\hline $\mathrm{AB} 4 \leftarrow \mathrm{AB}$ & 1.238 & 0.094 & 13.203 & $* * *$ \\
\hline $\mathrm{AB} 3 \leftarrow \mathrm{AB}$ & 1.119 & 0.084 & 13.240 & $* * *$ \\
\hline $\mathrm{AB} 2 \leftarrow \mathrm{AB}$ & 1.118 & 0.083 & 13.547 & $* * *$ \\
\hline $\mathrm{AB} 1 \leftarrow \mathrm{AB}$ & 1.000 & & & \\
\hline $\mathrm{SN} 5 \leftarrow \mathrm{SN}$ & 0.703 & 0.061 & 11.511 & $* * *$ \\
\hline $\mathrm{SN} 4 \leftarrow \mathrm{SN}$ & 0.729 & 0.061 & 11.938 & $* * *$ \\
\hline $\mathrm{SN} 3 \leftarrow \mathrm{SN}$ & 0.918 & 0.062 & 14.696 & $* * *$ \\
\hline $\mathrm{SN} 2 \leftarrow \mathrm{SN}$ & 0.954 & 0.053 & 18.018 & $* * *$ \\
\hline $\mathrm{SN} 1 \leftarrow \mathrm{SN}$ & 1.000 & & & \\
\hline $\mathrm{PBC} 5 \leftarrow \mathrm{PBC}$ & 0.954 & 0.065 & 14.578 & $* * *$ \\
\hline $\mathrm{PBC} 4 \leftarrow \mathrm{PBC}$ & 0.942 & 0.068 & 13.935 & $* * *$ \\
\hline $\mathrm{PBC} 3 \leftarrow \mathrm{PBC}$ & 1.011 & 0.057 & 17.723 & $* * *$ \\
\hline $\mathrm{PBC} 2 \leftarrow \mathrm{PBC}$ & 0.980 & 0.054 & 18.290 & $* * *$ \\
\hline $\mathrm{PBC} 1 \leftarrow \mathrm{PBC}$ & 1.000 & & & \\
\hline $\mathrm{TF} 5 \leftarrow \mathrm{TF}$ & 0.898 & 0.079 & 11.370 & $* * *$ \\
\hline $\mathrm{TF} 4 \leftarrow \mathrm{TF}$ & 0.906 & 0.080 & 11.331 & $* * *$ \\
\hline $\mathrm{TF} 3 \leftarrow \mathrm{TF}$ & 1.189 & 0.088 & 13.514 & $* * *$ \\
\hline $\mathrm{TF} 2 \leftarrow \mathrm{TF}$ & 1.027 & 0.087 & 11.735 & $* * *$ \\
\hline $\mathrm{TF} 1 \leftarrow \mathrm{TF}$ & 1.000 & & & \\
\hline $\mathrm{EV} 5 \leftarrow \mathrm{EV}$ & 1.085 & 0.108 & 10.044 & $* * *$ \\
\hline $\mathrm{EV} 4 \leftarrow \mathrm{EV}$ & 1.376 & 0.120 & 11.464 & $* * *$ \\
\hline $\mathrm{EV} 3 \leftarrow \mathrm{EV}$ & 1.309 & 0.113 & 11.571 & $* * *$ \\
\hline $\mathrm{EV} 2 \leftarrow \mathrm{EV}$ & 1.297 & 0.108 & 11.977 & $* * *$ \\
\hline $\mathrm{EV} 1 \leftarrow \mathrm{EV}$ & 1.000 & & & \\
\hline $\mathrm{IE} 5 \leftarrow \mathrm{IE}$ & 0.758 & 0.063 & 12.059 & $* * *$ \\
\hline $\mathrm{IE} 4 \leftarrow \mathrm{IE}$ & 0.642 & 0.062 & 10.290 & $* * *$ \\
\hline $\mathrm{IE} 3 \leftarrow \mathrm{IE}$ & 0.861 & 0.059 & 14.505 & $* * *$ \\
\hline $\mathrm{IE} 2 \leftarrow \mathrm{IE}$ & 0.966 & 0.053 & 18.265 & $* * *$ \\
\hline $\mathrm{IE} 1 \leftarrow \mathrm{IE}$ & 1.000 & & & \\
\hline $\mathrm{GS} 4 \leftarrow \mathrm{GS}$ & 0.831 & 0.050 & 16.546 & $* * *$ \\
\hline $\mathrm{GS} 3 \leftarrow \mathrm{GS}$ & 1.006 & 0.047 & 21.298 & $* * *$ \\
\hline $\mathrm{GS} 2 \leftarrow \mathrm{GS}$ & 0.934 & 0.043 & 21.875 & $* * *$ \\
\hline $\mathrm{GS} 1 \leftarrow \mathrm{GS}$ & 1.000 & & & \\
\hline $\mathrm{BI} 5 \leftarrow \mathrm{BI}$ & 1.029 & 0.067 & 14.170 & $* * *$ \\
\hline $\mathrm{BI} 4 \leftarrow \mathrm{BI}$ & 0.996 & 0.068 & 15.367 & $* * *$ \\
\hline $\mathrm{BI} 3 \leftarrow \mathrm{BI}$ & 0.946 & 0.065 & 13.914 & $* * *$ \\
\hline $\mathrm{BI} 2 \leftarrow \mathrm{BI}$ & 1.047 & 0.073 & 15.626 & $* * *$ \\
\hline $\mathrm{BI} 1 \leftarrow \mathrm{BI}$ & 1.000 & & & \\
\hline $\mathrm{B} 5 \leftarrow \mathrm{B}$ & 0.646 & 0.058 & 11.056 & $* * *$ \\
\hline $\mathrm{B} 4 \leftarrow \mathrm{B}$ & 0.994 & 0.050 & 19.744 & $* * *$ \\
\hline $\mathrm{B} 3 \leftarrow \mathrm{B}$ & 1.054 & 0.050 & 21.150 & $* * *$ \\
\hline $\mathrm{B} 2 \leftarrow \mathrm{B}$ & 1.057 & 0.045 & 23.354 & $* * *$ \\
\hline $\mathrm{B} 1 \leftarrow \mathrm{B}$ & 1.000 & & & \\
\hline
\end{tabular}

Note: ${ }^{* * *}$ Statistically significant at the 0.001 level of confidence.

Similar to Cronbach's $\alpha$, construct reliability (CR) as a reliability index for testing latent variables. The higher the value of the $C R$, the higher the consistency of the internal consistency, and the 0.7 is an acceptable threshold [105]. The average of variance extracted 
(AVE) was also calculated. AVE calculates the explanatory power of variation of latent variables. The higher AVE is, the greater the percentage of variation of indicator variables explained by latent variables will be. Fornell and Larcker [105] suggested that the ideal value should be greater than 0.5 .

The composition reliability and average of variance extracted of the nine latent variables can be calculated as shown in Table 5 .

Table 5. Construct reliability (CR) values and the average of variance extracted (AVE) values of the initial model.

\begin{tabular}{|c|c|c|c|c|c|}
\hline $\begin{array}{c}\text { Latent } \\
\text { Variables }\end{array}$ & Items & $\begin{array}{l}\text { Standardized Factor } \\
\text { Load Estimation }\end{array}$ & CR Values & AVE Values & Judgment \\
\hline \multirow{5}{*}{$\mathrm{AB}$} & AB1 & 0.818 & \multirow{5}{*}{0.9015} & \multirow{5}{*}{0.647} & \multirow{5}{*}{$\sqrt{ }$} \\
\hline & AB2 & 0.818 & & & \\
\hline & AB3 & 0.807 & & & \\
\hline & AB4 & 0.822 & & & \\
\hline & AB5 & 0.755 & & & \\
\hline \multirow{5}{*}{$\mathrm{SN}$} & SN1 & 0.888 & \multirow{5}{*}{0.8962} & \multirow{5}{*}{0.6369} & \multirow{5}{*}{$\sqrt{ }$} \\
\hline & SN2 & 0.902 & & & \\
\hline & SN3 & 0.814 & & & \\
\hline & SN4 & 0.689 & & & \\
\hline & SN5 & 0.667 & & & \\
\hline \multirow{5}{*}{ PBC } & PBC1 & 0.882 & \multirow{5}{*}{0.9245} & \multirow{5}{*}{0.711} & \multirow{5}{*}{$\sqrt{ }$} \\
\hline & PBC2 & 0.897 & & & \\
\hline & PBC3 & 0.885 & & & \\
\hline & PBC4 & 0.760 & & & \\
\hline & PBC5 & 0.782 & & & \\
\hline \multirow{5}{*}{$\mathrm{BI}$} & BI1 & 0.828 & \multirow{5}{*}{0.9262} & \multirow{5}{*}{0.7154} & \multirow{5}{*}{$\sqrt{ }$} \\
\hline & $\mathrm{BI} 2$ & 0.879 & & & \\
\hline & $\mathrm{BI} 3$ & 0.812 & & & \\
\hline & $\mathrm{BI} 4$ & 0.876 & & & \\
\hline & BI5 & 0.832 & & & \\
\hline \multirow{5}{*}{$\mathrm{TF}$} & TF1 & 0.755 & \multirow{5}{*}{0.8992} & \multirow{5}{*}{0.6419} & \multirow{5}{*}{$\sqrt{ }$} \\
\hline & TF2 & 0.795 & & & \\
\hline & TF3 & 0.903 & & & \\
\hline & TF4 & 0.770 & & & \\
\hline & TF5 & 0.774 & & & \\
\hline \multirow{5}{*}{ EV } & EV1 & 0.716 & \multirow{5}{*}{0.9031} & \multirow{5}{*}{0.6525} & \multirow{5}{*}{$\sqrt{ }$} \\
\hline & EV2 & 0.872 & & & \\
\hline & EV3 & 0.858 & & & \\
\hline & EV4 & 0.853 & & & \\
\hline & EV5 & 0.725 & & & \\
\hline & IE1 & 0.808 & & & \\
\hline & IE2 & 0.818 & & & \\
\hline $\mathrm{IE}$ & IE3 & 0.828 & 0.8869 & 0.6117 & $\sqrt{ }$ \\
\hline & IE4 & 0.679 & & & \\
\hline & IE5 & 0.768 & & & \\
\hline & GS1 & 0.905 & & & \\
\hline & GS2 & 0.925 & & & \\
\hline GS & GS3 & 0.919 & 0.9413 & 0.8008 & $\sqrt{ }$ \\
\hline & GS4 & 0.827 & & & \\
\hline & B1 & 0.922 & & & \\
\hline & B2 & 0.923 & & & \\
\hline B & B3 & 0.900 & 0.9335 & 0.7402 & $\sqrt{ }$ \\
\hline & B4 & 0.877 & & & \\
\hline & B5 & 0.648 & & & \\
\hline
\end{tabular}

Note: $\sqrt{ }$ represent the acceptable threshold.

The goodness of fit of the initial model is shown in Table 6. From Table 6, most of the goodness-of-fit indices satisfy their corresponding acceptable requirements. However, the measures of AGFI (Adjusted Goodness of Fit), NFI (Normed Fit Index), and RFI (Relative Fit Index) could not pass the acceptance level, indicating that the model needs to be optimized. 
Table 6. Goodness-of-fit of the initial model.

\begin{tabular}{lcccc}
\hline \multicolumn{2}{c}{ Goodness-of-Fit Measure } & Level of Acceptance Fit & Fit Statistics & Judgment \\
\hline \multirow{4}{*}{ Absolute fit } & $\chi^{2} / \mathrm{df}$ & $<5$ acceptable; $<3$ good & 1.805 & $\sqrt{ }$ \\
& GFI & $>0.8$ acceptable; $>0.9$ & 0.817 & $\sqrt{ }$ \\
& good & & $\times$ \\
& AGFI & $>0.8$ acceptable; $>0.9$ & 0.777 & \\
& good & & $\sqrt{ }$ \\
& RMSEA & $<0.1$ acceptable; $<0.08$ & 0.062 & $\times$ \\
Incremental fit & good & 0.84 & $\times$ \\
& NFI & $>0.9$ & 0.816 & $\sqrt{ }$ \\
& RFI & $>0.9$ & 0.925 & $\sqrt{ }$ \\
\hline
\end{tabular}

Note: $\sqrt{ }$ represent the acceptable threshold; $\times$ represent the unacceptable threshold.

\subsubsection{Model Modification}

According to the path coefficient derived from the initial model testing, the $p$-value of the path from TF to B is 0.850 (see Table 4), indicating that the path is not significant [106]. Similar analysis procedures were conducted with the updated model. The derived results showed that the $p$-value of the path from IE to B was 0.632 , which was still not significant. Therefore, the hypothesis of $\mathrm{H7}$ was rejected. After several rounds of modification, the paths $\mathrm{PBC} \rightarrow \mathrm{BI}$, BI $\rightarrow$ B were subsequently deleted, and the modified final structural model was derived, as shown in Figure 4.

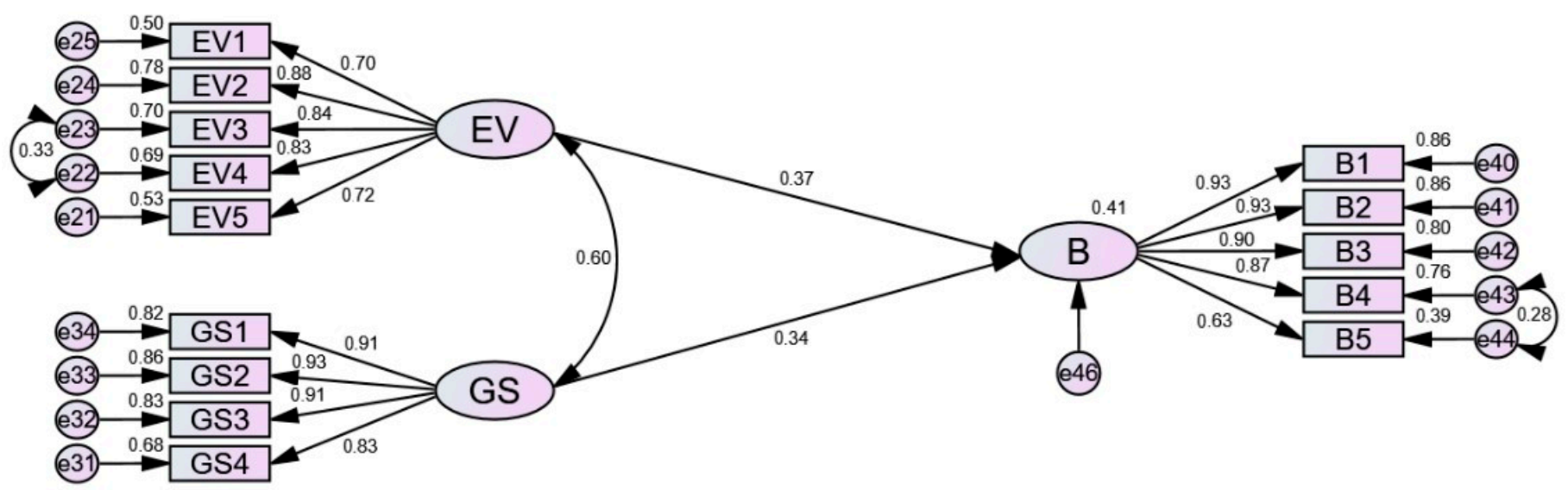

Figure 4. Standardized estimation of the final model.

The path coefficients of the final model are shown in Table 7. From Table 7, it can be seen that the two paths from EV and GS to B are significant at the level of 0.001 .

From Table 8, all the goodness-of-fit indices are within the acceptable levels, indicating the final model fits the data very well. Thus, it can be concluded that economic viability (EV) and governmental supervision (GS) are the two determinants of influencing construction professionals' BIM adoption behavior.

Figure 4 illustrates the relationships between EV, GS, and B. It can be seen that the path weight from latent variable EV to B is 0.37 , which means that when EV goes up by 1 standard deviation, the construction professionals' BIM adoption behavior goes up by 0.37 standard deviations. Similarly, the path weight from latent variable GS to B is 0.34 , meaning when GS goes up by 1 standard deviation, BIM adoption behavior goes up by 0.40 standard deviations. 
Table 7. Path Coefficient of the final model.

\begin{tabular}{ccccc}
\hline Model Path & Estimate & S.E. & C.R. & $p$ \\
\hline B $\leftarrow$ EV & 0.696 & 0.155 & 4.502 & $* * *$ \\
B $\leftarrow$ GS & 0.421 & 0.096 & 4.401 & $* * *$ \\
EV5 $\leftarrow$ EV & 1.100 & 0.113 & 9.732 & $* * *$ \\
EV4 $\leftarrow$ EV & 1.363 & 0.127 & 10.758 & $* * *$ \\
EV3 $\leftarrow$ EV & 1.294 & 0.119 & 10.843 & $* * *$ \\
EV2 $\leftarrow$ EV & 1.331 & 0.114 & 11.640 & $* * *$ \\
EV1 $\leftarrow$ EV & 1.000 & & & $* * *$ \\
GS4 $\leftarrow$ GS & 0.825 & 0.050 & 16.514 & $* * *$ \\
GS3 $\leftarrow$ GS & 0.996 & 0.047 & 21.202 & $*$ \\
GS2 $\leftarrow$ GS & 0.931 & 0.042 & 22.110 & $* * *$ \\
GS1 $\leftarrow$ GS & 1.000 & & & $* * *$ \\
B5 $\leftarrow$ B & 0.622 & 0.059 & 10.588 & $* .496$ \\
B4 $\leftarrow$ B & 0.980 & 0.050 & 21.175 & \\
B3 $\leftarrow$ B & 1.046 & 0.049 & 23.864 & \\
B2 $\leftarrow$ B & 1.056 & 0.044 & & \\
B1 $\leftarrow$ B & 1.000 & &
\end{tabular}

Table 8. Goodness-of-fit of the final model.

\begin{tabular}{|c|c|c|c|c|}
\hline \multicolumn{2}{|c|}{ Goodness-of-Fit Measure } & Level of Acceptance Fit & \multirow{2}{*}{$\begin{array}{c}\text { Fit Statistics } \\
2.328\end{array}$} & \multirow{2}{*}{$\begin{array}{c}\text { Judgment } \\
\sqrt{ }\end{array}$} \\
\hline \multirow{4}{*}{ Absolute fit } & $x^{2} / \mathrm{df}$ & $<5$ acceptable $;<3$ good & & \\
\hline & GFI & $\begin{array}{c}>0.8 \text { acceptable } ;>0.9 \\
\text { good }\end{array}$ & 0.921 & $\sqrt{ }$ \\
\hline & AGFI & $>0.8$ acceptable; $>0.9$ & 0.893 & $\sqrt{ }$ \\
\hline & RMSEA & $\begin{array}{l}<0.1 \text { acceptable } ;<0.08 \\
\text { good }\end{array}$ & 0.069 & $\sqrt{ }$ \\
\hline \multirow{5}{*}{ Incremental fit } & NFI & $>0.9$ & 0.932 & $\sqrt{ }$ \\
\hline & RFI & $>0.9$ & 0.914 & $\sqrt{ }$ \\
\hline & IFI & $>0.9$ & 0.958 & $\sqrt{ }$ \\
\hline & TLI & $>0.9$ & 0.946 & $\sqrt{ }$ \\
\hline & CFI & $>0.9$ & 0.957 & $\sqrt{ }$ \\
\hline
\end{tabular}

Note: $\sqrt{ }$ represent the acceptable threshold.

\section{Discussion}

In the existing literature, studies on the influencing factors of BIM adoption have been conducted. Sun et al. [107] identified 22 influencing factors of BIM adoption from literature and classified them into five categories: technology, cost, management, personnel, and legal. However, the influencing factors of BIM adoption may vary in different countries or regions. For example, Alreshidi et al. [108] revealed that social-organizational theme, financial theme, technical theme, contractual theme, and legal theme are the five main themes of BIM adoption barriers in the UK. Ngowtanasawan [109] focused on the architectural and engineering design industry in Thailand and divided the BIM adoption factors into technology and people aspects. Hatem et al. [110] identified the motivation factors of BIM implementation in Iraq, such as contracting with international experts. Furthermore, Hatem et al. [111] revealed the barriers of BIM adoption, such as weakness of the government's efforts, inadequate knowledge about the benefits of BIM, and resistance to change. In Hong Kong, the resistance to change by construction stakeholders was also regarded as the main barrier of BIM implementation [112]. In addition, inadequate organizational support and structure to execute BIM and lack of BIM industry standards were considered another two main barriers [112]. Ahuja et al. [113] investigated the construction market in India and categorized the BIM adoption factors into three groups, such as technological factors, organizational factors, and environmental factors.

China has a large construction market, the construction industry value in China amounted to 893.58 billion U.S. dollars in 2018 and has an increasing trend [114]. In recent 
years, BIM has got extensive attentions from the AEC industry and the investment in promoting BIM is expected to be increased [115]. From this survey, it can be seen that the research institutions in China have paid concentration on BIM adoption; however, the BIM adoption in practice is still insufficient, most of the respondents participated in less than five BIM projects. According to the results derived in this study, it can be concluded that, in the context of China, economic viability and governmental supervision are the two determinants for construction professionals' BIM adoption. These two factors are also recognized in the UK investigation [108]. Nevertheless, behavioral intentions, technical feasibility, and industrial environment, which are often regarded as significant affecting factors in other countries, are insignificant in the Chinese context.

In order to verify the modeling results, three construction professionals who have rich experiences in practical BIM implementation were interviewed to collect their comments. All of the three interviewees were not surprised that behavioral intention is not a significant affecting factor for BIM adoption. They argued that making BIM adoption decision is usually organizational behavior rather than individual behavior. The individuals normally have no authority to decide using BIM or not. In terms of the technical feasibility, the three interviewees also agreed with the empirical result. They acknowledged that many technical issues were encountered during their practical implementation of BIM. For example, one interviewee claimed that though a main advantage of BIM is data interaction between different stakeholders, the contractor must rebuild the model as the architectural designer used different software in many of his previous projects. However, at present, there have been several famous localized BIM related software producers that can provide timely and effective technical support when encountering technical problems. In addition, the three interviewees believed that the current technical issues will diminished as BIM technologies develop. In terms of the industrial environment, different from the analysis results, one of the three interviewees regarded the industrial environment is a significant affecting factor for BIM adoption. He argued that BIM is a technology that involves all participants throughout the whole lifecycle of a project, and it is a must that general agreements to be achieved for BIM promotion. However, the other two interviewees claimed that the industrial environment is mainly affected by outside forces (e.g., government policies) rather than the industry itself. If there are strong outside forces that promote BIM adoption, the industrial environment will be improved automatically as the development of BIM technology. For example, suppose a project is designed aiming to obtain industrial prizes. In that case, it is usually a prior option to adopt BIM because it can help earn more scores during the assessment.

All of the three interviewees agreed that economic viability and governmental supervision are the two determinants of BIM adoption. This is echoed with the findings from Ding, Zuo, Wu and Wang [89] which investigated the architects' perspectives. It is not difficult to understand that economic viability is a determinant because the nature of a construction company is to gain profits. The profits of adopting BIM can be obtained from cost management, schedule optimization, reduction of design change, etc. At the beginning of BIM technology development, it is unavoidable that there are many technical issues and the industrial environment is not mature; governmental supervision is important in this circumstance. $\mathrm{Xu}$, Feng and $\mathrm{Li}$ [86] also claimed that the promotion from the government is essential to companies to adopt the BIM technology. Actually, in some cities of China (e.g., Shenzhen and Guangzhou), the government requires contractors to adopt BIM in government investment projects in order to promote BIM development.

\section{Conclusions}

Building information modeling (BIM) has received growing interest from the construction industry in recent years. Based on the theory of planned behavior, this study established an initial hypothesis model containing nine latent variables and designed a questionnaire to measure the established model. After the analysis of reliability and validity, the goodness-of-fit of the proposed model was tested by SEM. The empirical results showed 
that the construction professionals are willing to adopt BIM in their projects; although, the advantages of BIM cannot be realized sufficiently at this stage. The SEM analysis revealed that economic viability and governmental supervision are the critical factors of construction professionals' BIM adoption behavior, sharing weights of 0.37 and 0.34 respectively, whereas behavioral intentions, technical feasibility, and industrial environment are not influential in this regard.

The research findings of this study have practical contributions for promoting BIM development in China. They may also be applicable in other developing countries; however, future research is suggested to be conducted in the local context. Based on the derived results, it is suggested that focus should be paid mainly on the economic viability and governmental supervision aspects to promote BIM adoption at this stage. In this regard, the government can play a significant role. Policies (e.g., awarding credits to BIM adoption during project assessment) can be issued to guide stakeholders to adopt BIM technology.

This study has some limitations. For example, the sample size collected in this study is 206, which is not so sufficient for employing SEM. Future research is suggested to collect a more significant number of responses.

Author Contributions: Conceptualization, Z.W. and M.J.; methodology, Z.W. and M.J.; validation, M.J.; writing-original draft preparation, Z.W. and M.J.; writing-review and editing, H.L., X.L. (Xiaoying Li), and X.L. (Xiaochun Luo). All authors have read and agreed to the published version of the manuscript.

Funding: This research was funded by the General Research Fund (GRF) Grant (grant numbers PolyU 152047/19E, BRE/PolyU 15210720). This study also received support from the Research Start-up Funding in Shenzhen (grant number 000376).

Institutional Review Board Statement: Not applicable.

Informed Consent Statement: Not applicable.

Conflicts of Interest: The authors declare no conflict of interest.

\section{References}

1. Wang, H.; Pan, Y.; Luo, X.C. Integration of BIM and GIS in sustainable built environment: A review and bibliometric analysis. Autom. Constr. 2019, 103, 41-52. [CrossRef]

2. Wu, Z.; He, Q.; Yang, K.; Zhang, J.; Xu, K. Investigating the Dynamics of China's Green Building Policy Development from 1986 to 2019. Int. J. Environ. Res. Public Health 2021, 18, 196. [CrossRef]

3. Lewis, A.M.; Valdes-Vasquez, R.; Clevenger, C. Understanding the perceived value of using BIM for energy simulation. J. Green Build. 2019, 14, 79-92. [CrossRef]

4. Mostafa, S.; Kim, K.P.; Tam, V.W.Y.; Rahnamayiezekavat, P. Exploring the status, benefits, barriers and opportunities of using BIM for advancing prefabrication practice. Int. J. Constr. Manag. 2020, 20, 146-156. [CrossRef]

5. Davidson, J.; Fowler, J.; Pantazis, C.; Sannino, M.; Walker, J.; Sheikhkhoshkar, M.; Rahimian, F.P. Integration of VR with BIM to facilitate real-time creation of bill of quantities during the design phase: A proof of concept study. Front. Eng. Manag. 2020, 7 , 396-403. [CrossRef]

6. Hou, C.; Wen, Y.; He, Y.; Liu, X.; Wang, M.; Zhang, Z.; Fu, H. Public stereotypes of recycled water end uses with different human contact: Evidence from event-related potential (ERP). Resour. Conserv. Recycl. 2021, 168, 105464. [CrossRef]

7. Jung, Y.; Chin, S.; Kim, K. Informatization index for the construction industry. J. Comput. Civ. Eng. 2004, 18, 267-276. [CrossRef]

8. Lu, W.S.; Peng, Y.; Shen, Q.P.; Li, H. Generic model for measuring benefits of BIM as a learning tool in construction tasks. J. Constr. Eng. Manag. 2013, 139, 195-203. [CrossRef]

9. Cao, D.P.; Li, H.; Wang, G.B.; Luo, X.C.; Yang, X.C.; Tan, D. Dynamics of Project-Based Collaborative Networks for BIM Implementation: Analysis Based on Stochastic Actor-Oriented Models. J. Manag. Eng. 2017, 33, 12. [CrossRef]

10. Khanzadi, M.; Sheikhkhoshkar, M.; Banihashemi, S. BIM applications toward key performance indicators of construction projects in Iran. Int. J. Constr. Manag. 2020, 20, 305-320. [CrossRef]

11. Naticchia, B.; Corneli, A.; Carbonari, A. Framework based on building information modeling, mixed reality, and a cloud platform to support information flow in facility management. Front. Eng. Manag. 2020, 7, 131-141. [CrossRef]

12. Zhang, L.; Sun, X.; Xue, H. Identifying critical risks in Sponge City PPP projects using DEMATEL method: A case study of China. J. Clean. Prod. 2019, 226, 949-958. [CrossRef]

13. NIBS. National BIM Standar-United States ${ }^{\circledR}$ Version 3. Available online: http:/ / www.nationalbimstandard.org/files/NBIMSUS_V3_3_Terms_and_Definitions.pdf (accessed on 23 October 2018). 
14. NBS. What is Building Information Modelling (BIM)? Available online: https://www.thenbs.com/knowledge/what-is-buildinginformation-modelling-bim (accessed on 23 October 2018).

15. Zhao, X.B.; Wu, P.; Wang, X.Y. Risk paths in BIM adoption: Empirical study of China. Eng. Constr. Archit. Manag. 2018, 25, 1170-1187. [CrossRef]

16. Li, J.M.; Li, N.P.; Peng, J.Q.; Cui, H.J.; Wu, Z.B. A review of currently applied building information modeling tools of constructions in China. J. Clean. Prod. 2018, 201, 358-368. [CrossRef]

17. Cao, D.P.; Li, H.; Wang, G.B.; Luo, X.C.; Tan, D. Relationship Network Structure and Organizational Competitiveness: Evidence from BIM Implementation Practices in the Construction Industry. J. Manag. Eng. 2018, 34, 12. [CrossRef]

18. Soust-Verdaguer, B.; Llatas, C.; Garcia-Martinez, A. Critical review of bim-based LCA method to buildings. Energy Build. 2017, 136, 110-120. [CrossRef]

19. Li, X.; Li, H.; Cao, D.; Tang, Y.; Luo, X.; Wang, G. Modeling Dynamics of Project-Based Collaborative Networks for BIM Implementation in the Construction Industry: Empirical Study in Hong Kong. J. Constr. Eng. Manag. 2019, 145, 05019013. [CrossRef]

20. Li, M.; Ma, Z.; Tang, X. Owner-dominated building information modeling and lean construction in a megaproject. Front. Eng. Manag. 2021, 8, 60-71. [CrossRef]

21. Marzouk, M.; Azab, S.; Metawie, M. BIM-based approach for optimizing life cycle costs of sustainable buildings. J. Clean. Prod. 2018, 188, 217-226. [CrossRef]

22. Dixit, M.K.; Venkatraj, V.; Ostadalimakhmalbaf, M.; Pariafsai, F.; Lavy, S. Integration of facility management and building information modeling (BIM). Facilities 2019, 37, 455-483. [CrossRef]

23. Marzouk, M.; Othman, A. Modeling the performance of sustainable sanitation systems using building information modeling. J. Clean. Prod. 2017, 141, 1400-1410. [CrossRef]

24. Park, J.H.; Lee, G. Design coordination strategies in a 2D and BIM mixed-project environment: Social dynamics and productivity. Build. Res. Inf. 2017, 45, 631-648. [CrossRef]

25. Tan, Y.; Song, Y.; Liu, X.; Wang, X.; Cheng, J.C. A BIM-based framework for lift planning in topsides disassembly of offshore oil and gas platforms. Autom. Constr. 2017, 79, 19-30. [CrossRef]

26. Hilal, M.; Maqsood, T.; Abdekhodaee, A. A hybrid conceptual model for BIM in FM. Constr. Innov. 2019, 4, 531-549. [CrossRef]

27. Martínez-Aires, M.D.; Lopez-Alonso, M.; Martinez-Rojas, M. Building information modeling and safety management: A systematic review. Saf. Sci. 2018, 101, 11-18. [CrossRef]

28. Alwan, Z.; Jones, P.; Holgate, P. Strategic sustainable development in the UK construction industry, through the framework for strategic sustainable development, using Building Information Modelling. J. Clean. Prod. 2017, 140, 349-358. [CrossRef]

29. Chong, H.-Y.; Lee, C.-Y.; Wang, X. A mixed review of the adoption of Building Information Modelling (BIM) for sustainability. J. Clean. Prod. 2017, 142, 4114-4126. [CrossRef]

30. Lu, Y.; Wu, Z.; Chang, R.; Li, Y. Building Information Modeling (BIM) for green buildings: A critical review and future directions. Autom. Constr. 2017, 83, 134-148. [CrossRef]

31. Ding, Z.; Liu, S.; Liao, L.; Zhang, L. A digital construction framework integrating building information modeling and reverse engineering technologies for renovation projects. Autom. Constr. 2019, 102, 45-58. [CrossRef]

32. GhaffarianHoseini, A.; Doan, D.T.; Naismith, N.; Tookey, J.; GhaffarianHoseini, A. Amplifying the practicality of contemporary building information modelling (BIM) implementations for New Zealand green building certification (Green Star). Eng. Constr. Archit. Manag. 2017, 24, 696-714. [CrossRef]

33. Marzouk, M.; Abdelkader, E.M.; Al-Gahtani, K. Building information modeling-based model for calculating direct and indirect emissions in construction projects. J. Clean. Prod. 2017, 152, 351-363. [CrossRef]

34. Peng, C. Calculation of a building's life cycle carbon emissions based on Ecotect and building information modeling. J. Clean. Prod. 2016, 112, 453-465. [CrossRef]

35. Yang, X.; Hu, M.; Wu, J.; Zhao, B. Building-information-modeling enabled life cycle assessment, a case study on carbon footprint accounting for a residential building in China. J. Clean. Prod. 2018, 183, 729-743. [CrossRef]

36. Eleftheriadis, S.; Mumovic, D.; Greening, P. Life cycle energy efficiency in building structures: A review of current developments and future outlooks based on BIM capabilities. Renew. Sustain. Energy Rev. 2017, 67, 811-825. [CrossRef]

37. Alwisy, A.; Bu Hamdan, S.; Barkokebas, B.; Bouferguene, A.; Al-Hussein, M. A BIM-based automation of design and drafting for manufacturing of wood panels for modular residential buildings. Int. J. Constr. Manag. 2019, 19, 187-205. [CrossRef]

38. Singh, M.M.; Sawhney, A.; Borrmann, A. Integrating rules of modular coordination to improve model authoring in BIM. Int. J. Constr. Manag. 2019, 19, 15-31. [CrossRef]

39. Tan, T.; Chen, K.; Xue, F.; Lu, W. Barriers to Building Information Modeling (BIM) implementation in China's prefabricated construction: An interpretive structural modeling (ISM) approach. J. Clean. Prod. 2019, 219, 949-959. [CrossRef]

40. Wang, Y.; Li, H.; Wu, Z. Attitude of the Chinese public toward off-site construction: A text mining study. J. Clean. Prod. 2019, 238, 117926. [CrossRef]

41. Saieg, P.; Sotelino, E.D.; Nascimento, D.; Caiado, R.G.G. Interactions of Building Information Modeling, Lean and Sustainability on the Architectural, Engineering and Construction industry: A systematic review. J. Clean. Prod. 2018, 174, 788-806. [CrossRef]

42. Chen, K.; Lu, W.; Xue, F.; Tang, P.; Li, L.H. Automatic building information model reconstruction in high-density urban areas: Augmenting multi-source data with architectural knowledge. Autom. Constr. 2018, 93, 22-34. [CrossRef] 
43. Hossain, M.A.; Abbott, E.L.; Chua, D.K.; Nguyen, T.Q.; Goh, Y.M. Design-for-safety knowledge library for BIM-integrated safety risk reviews. Autom. Constr. 2018, 94, 290-302. [CrossRef]

44. Cao, D.P.; Li, H.; Wang, G.B. Impacts of building information modeling (BIM) implementation on design and construction performance: A resource dependence theory perspective. Front. Eng. Manag. 2017, 4, 20-34. [CrossRef]

45. Pham, K.-T.; Vu, D.-N.; Hong, P.L.H.; Park, C. 4D-BIM-Based Workspace Planning for Temporary Safety Facilities in Construction SMEs. Int. J. Environ. Res. Public Health 2020, 17, 3403. [CrossRef]

46. Sanhudo, L.; Ramos, N.M.; Martins, J.P.; Almeida, R.M.; Barreira, E.; Simões, M.L.; Cardoso, V. Building information modeling for energy retrofitting-A review. Renew. Sustain. Energy Rev. 2018, 89, 249-260. [CrossRef]

47. Tan, Y.; Fang, Y.; Zhou, T.; Gan, V.J.; Cheng, J.C. BIM-supported 4D acoustics simulation approach to mitigating noise impact on maintenance workers on offshore oil and gas platforms. Autom. Constr. 2019, 100, 1-10. [CrossRef]

48. Cao, D.; Li, H.; Wang, G.; Huang, T. Identifying and contextualising the motivations for BIM implementation in construction projects: An empirical study in China. Int. J. Proj. Manag. 2017, 35, 658-669. [CrossRef]

49. Kim, K.; Teizer, J. Automatic design and planning of scaffolding systems using building information modeling. Adv. Eng. Inform. 2014, 28, 66-80. [CrossRef]

50. Wang, J.; Wang, X.; Shou, W.; Chong, H.-Y.; Guo, J. Building information modeling-based integration of MEP layout designs and constructability. Autom. Constr. 2016, 61, 134-146. [CrossRef]

51. Wang, X.; Love, P.E.; Kim, M.J.; Park, C.-S.; Sing, C.-P.; Hou, L. A conceptual framework for integrating building information modeling with augmented reality. Autom. Constr. 2013, 34, 37-44. [CrossRef]

52. Wu, Z.; Chen, C.; Cai, Y.; Lu, C.; Wang, H.; Yu, T. BIM-Based Visualization Research in the Construction Industry: A Network Analysis. Int. J. Environ. Res. Public Health 2019, 16, 3473. [CrossRef] [PubMed]

53. Rahimian, F.P.; Ibrahim, R.; Wang, J.; Wang, X.; Shou, W.; Xu, B. Integrating BIM and augmented reality for interactive architectural visualisation. Constr. Innov. 2014, 4, 453-476.

54. Ding, L.; Xu, X. Application of cloud storage on BIM life-cycle management. Int. J. Adv. Robot. Syst. 2014, 11, 129. [CrossRef]

55. Zhou, Y.; Ding, L.; Rao, Y.; Luo, H.; Medjdoub, B.; Zhong, H. Formulating project-level building information modeling evaluation framework from the perspectives of organizations: A review. Autom. Constr. 2017, 81, 44-55. [CrossRef]

56. Antwi-Afari, M.; Li, H.; Pärn, E.; Edwards, D. Critical success factors for implementing building information modelling (BIM): A longitudinal review. Autom. Constr. 2018, 91, 100-110. [CrossRef]

57. Zhang, X.; Azhar, S.; Nadeem, A.; Khalfan, M. Using Building Information Modelling to achieve Lean principles by improving efficiency of work teams. Int. J. Constr. Manag. 2018, 18, 293-300. [CrossRef]

58. Love, P.E.; Simpson, I.; Hill, A.; Standing, C. From justification to evaluation: Building information modeling for asset owners. Autom. Constr. 2013, 35, 208-216. [CrossRef]

59. Love, P.E.; Matthews, J.; Simpson, I.; Hill, A.; Olatunji, O.A. A benefits realization management building information modeling framework for asset owners. Autom. Constr. 2014, 37, 1-10. [CrossRef]

60. Wang, K.-C.; Wang, W.-C.; Wang, H.-H.; Hsu, P.-Y.; Wu, W.-H.; Kung, C.-J. Applying building information modeling to integrate schedule and cost for establishing construction progress curves. Autom. Constr. 2016, 72, 397-410. [CrossRef]

61. Akinade, O.O.; Oyedele, L.O.; Ajayi, S.O.; Bilal, M.; Alaka, H.A.; Owolabi, H.A.; Arawomo, O.O. Designing out construction waste using BIM technology: Stakeholders' expectations for industry deployment. J. Clean. Prod. 2018, 180, 375-385. [CrossRef]

62. Lu, W.; Webster, C.; Chen, K.; Zhang, X.; Chen, X. Computational Building Information Modelling for construction waste management: Moving from rhetoric to reality. Renew. Sustain. Energy Rev. 2017, 68, 587-595. [CrossRef]

63. Wang, J.; Wu, H.; Duan, H.; Zillante, G.; Zuo, J.; Yuan, H. Combining life cycle assessment and Building Information Modelling to account for carbon emission of building demolition waste: A case study. J. Clean. Prod. 2018, 172, 3154-3166. [CrossRef]

64. Li, J.; Wang, Y.; Wang, X.; Luo, H.; Kang, S.-C.; Wang, J.; Guo, J.; Jiao, Y. Benefits of building information modelling in the project lifecycle: Construction projects in Asia. Int. J. Adv. Robot. Syst. 2014, 11, 124. [CrossRef]

65. Luo, H.; Gong, P. A BIM-based code compliance checking process of deep foundation construction plans. J. Intell. Robot. Syst. 2015, 79, 549-576. [CrossRef]

66. Mancini, M.; Wang, X.Y.; Skitmore, M.; Issa, R. Editorial for IJPM special issue on advances in building information modeling (BIM) for construction projects. Int. J. Proj. Manag. 2017, 35, 656-657. [CrossRef]

67. Zhao, X.B.; Feng, Y.B.; Pienaar, J.; O’Brien, D. Modelling paths of risks associated with BIM implementation in architectural, engineering and construction projects. Archit. Sci. Rev. 2017, 60, 472-482. [CrossRef]

68. Venugopal, M.; Eastman, C.M.; Teizer, J. An ontology-based analysis of the industry foundation class schema for building information model exchanges. Adv. Eng. Inform. 2015, 29, 940-957. [CrossRef]

69. Gu, N.; London, K. Understanding and facilitating BIM adoption in the AEC industry. Autom. Constr. 2010, 19, 988-999. [CrossRef]

70. Succar, B. Building information modelling framework: A research and delivery foundation for industry stakeholders. Autom. Constr. 2009, 18, 357-375. [CrossRef]

71. Voordijk, H. Building information modeling and its impact on users in the lifeworld: A mediation perspective. Front. Eng. Manag. 2019, 6, 193-206. [CrossRef]

72. Enshassi, A.; Ayyash, A.; Choudhry, R.M. BIM for construction safety improvement in Gaza strip: Awareness, applications and barriers. Int. J. Constr. Manag. 2016, 16, 249-265. [CrossRef] 
73. Venugopal, M.; Eastman, C.M.; Sacks, R.; Teizer, J. Semantics of model views for information exchanges using the industry foundation class schema. Adv. Eng. Inform. 2012, 26, 411-428. [CrossRef]

74. Lee, Y.C.; Solihin, W.; Eastman, C.M. The Mechanism and Challenges of Validating a Building Information Model regarding data exchange standards. Autom. Constr. 2019, 100, 118-128. [CrossRef]

75. Abd Jamil, A.H.; Fathi, M.S. Contractual challenges for BIM-based construction projects: A systematic review. Built Environ. Proj. Asset Manag. 2018, 8, 372-385. [CrossRef]

76. Raouf, A.M.I.; Al-Ghamdi, S.G. Building information modelling and green buildings: Challenges and opportunities. Archit. Eng. Des. Manag. 2019, 15, 1-28. [CrossRef]

77. Teng, Y.; Li, X.; Wu, P.; Wang, X. Using cooperative game theory to determine profit distribution in IPD projects. Int. J. Constr. Manag. 2019, 19, 32-45. [CrossRef]

78. Yu, T.; Man, Q.; Wang, Y.; Shen, G.Q.; Hong, J.; Zhang, J.; Zhong, J. Evaluating different stakeholder impacts on the occurrence of quality defects in offsite construction projects: A Bayesian-network-based model. J. Clean. Prod. 2019, 241, 118390. [CrossRef]

79. Becerik-Gerber, B.; Jazizadeh, F.; Li, N.; Calis, G. Application areas and data requirements for BIM-enabled facilities management. J. Constr. Eng. Manag. 2012, 138, 431-442. [CrossRef]

80. Ding, L.; Zhou, Y.; Akinci, B. Building Information Modeling (BIM) application framework: The process of expanding from 3D to computable nD. Autom. Constr. 2014, 46, 82-93. [CrossRef]

81. Mohammad, W.; Abdullah, M.R.; Ismail, S.; Takim, R. Overview of Building Information Modelling (BIM) adoption factors for construction organisations. In Proceedings of the IOP Conference Series: Earth and Environmental Science; IOP Publishing: Bristol, UK, 2018; p. 012107.

82. Mom, M.; Tsai, M.-H.; Hsieh, S.-H. Developing critical success factors for the assessment of BIM technology adoption: Part II. Analysis and results. J. Chin. Inst. Eng. 2014, 37, 859-868. [CrossRef]

83. Ullah, K.; Raitviir, C.; Lill, I.; Witt, E. BIM adoption in the AEC/FM industry-the case for issuing building permits. Int. J. Strateg. Prop. Manag. 2020, 24, 400-413. [CrossRef]

84. Yadav, R.; Pathak, G.S. Determinants of consumers' green purchase behavior in a developing nation: Applying and extending the theory of planned behavior. Ecol. Econ. 2017, 134, 114-122. [CrossRef]

85. Wang, S.; Fan, J.; Zhao, D.; Yang, S.; Fu, Y.J.T. Predicting consumers' intention to adopt hybrid electric vehicles: Using an extended version of the theory of planned behavior model. Transportation 2016, 43, 123-143. [CrossRef]

86. Xu, H.; Feng, J.; Li, S. Users-orientated evaluation of building information model in the Chinese construction industry. Autom. Constr. 2014, 39, 32-46. [CrossRef]

87. Howard, R.; Restrepo, L.; Chang, C.Y. Addressing individual perceptions: An application of the unified theory of acceptance and use of technology to building information modelling. Int. J. Proj. Manag. 2017, 35, 107-120. [CrossRef]

88. Jin, R.Y.; Hancock, C.; Tang, L.; Chen, C.; Wanatowski, D.; Yang, L. Empirical Study of BIM Implementation-Based Perceptions among Chinese Practitioners. J. Manag. Eng. 2017, 33, 04017025. [CrossRef]

89. Ding, Z.K.; Zuo, J.; Wu, J.C.; Wang, J.Y. Key factors for the BIM adoption by architects: A China study. Eng. Constr. Archit. Manag. 2015, 22, 732-748. [CrossRef]

90. Lopez, R.; Chong, H.Y.; Wang, X.Y.; Graham, J. Technical Review: Analysis and Appraisal of Four-Dimensional Building Information Modeling Usability in Construction and Engineering Projects. J. Constr. Eng. Manag. 2016, 142, 6. [CrossRef]

91. Ghaffarianhoseini, A.; Tookey, J.; Ghaffarianhoseini, A.; Naismith, N.; Azhar, S.; Efimova, O.; Raahemifar, K. Building Information Modelling (BIM) uptake: Clear benefits, understanding its implementation, risks and challenges. Renew. Sustain. Energy Rev. 2017, 75, 1046-1053. [CrossRef]

92. Zou, Y.; Kiviniemi, A.; Jones, S.W. A review of risk management through BIM and BIM-related technologies. Saf. Sci. 2017, 97, 88-98. [CrossRef]

93. Cao, D.P.; Li, H.; Wang, G.B.; Zhang, W.J. Linking the Motivations and Practices of Design Organizations to Implement Building Information Modeling in Construction Projects: Empirical Study in China. J. Manag. Eng. 2016, 32, 10. [CrossRef]

94. Liao, L.H.; Teo, E.A.L. Critical success factors for enhancing the building information modelling implementation in building projects in Singapore. J. Civ. Eng. Manag. 2017, 23, 1029-1044. [CrossRef]

95. Lee, S.I.; Bae, J.S.; Cho, Y.S. Efficiency analysis of Set-based Design with structural building information modeling (S-BIM) on high-rise building structures. Autom. Constr. 2012, 23, 20-32. [CrossRef]

96. Porwal, A.; Hewage, K.N. Building Information Modeling (BIM) partnering framework for public construction projects. Autom. Constr. 2013, 31, 204-214. [CrossRef]

97. Sacks, R.; Gurevich, U.; Shrestha, P. A review of building information modeling protocols, guides and standards for large construction clients. J. Inf. Technol. Constr. 2016, 21, 479-503.

98. Papadonikolaki, E.; Wamelink, H. Inter- and intra-organizational conditions for supply chain integration with BIM. Build. Res. Inf. 2017, 45, 649-664. [CrossRef]

99. Cheng, J.C.P.; Lu, Q.Q. A review of the efforts and roles of the public sector for BIM adoption worldwide. J. Inf. Technol. Constr. 2015, 20, 442-478.

100. Chang, C.Y.; Pan, W.J.; Howard, R. Impact of Building Information Modeling Implementation on the Acceptance of Integrated Delivery Systems: Structural Equation Modeling Analysis. J. Constr. Eng. Manag. 2017, 143, 04017044. [CrossRef] 
101. Fan, S.L. Intellectual Property Rights in Building Information Modeling Application in Taiwan. J. Constr. Eng. Manag. 2014, 140, 04013058. [CrossRef]

102. Sambasivan, M.; Soon, Y.W. Causes and effects of delays in Malaysian construction industry. Int. J. Proj. Manag. 2007, 25, 517-526. [CrossRef]

103. Wu, Z.; Jiang, M.; Cai, Y.; Wang, H.; Li, S. What Hinders the Development of Green Building? An Investigation of China. Int. J. Environ. Res. Public Health 2019, 16, 3140. [CrossRef]

104. Wu, Z.; Yu, A.T.W.; Shen, L. Investigating the determinants of contractor's construction and demolition waste management behavior in Mainland China. Waste Manag. 2017, 60, 290-300. [CrossRef]

105. Fornell, C.; Larcker, D.F. Evaluating Structural Equation Models with Unobservable Variables and Measurement Error. J. Mark. Res. 1981, 18, 39-50. [CrossRef]

106. Thong, K.-C.; Wong, W.-P. Pathways for Sustainable Supply Chain Performance-Evidence from a Developing Country, Malaysia. Sustainability 2018, 10, 2781. [CrossRef]

107. Sun, C.S.; Jiang, S.H.; Skibniewski, M.J.; Man, Q.P.; Shen, L.Y. A literature review of the factors limiting the application of bim in the construction industry. Technol. Econ. Dev. Econ. 2017, 23, 764-779. [CrossRef]

108. Alreshidi, E.; Mourshed, M.; Rezgui, Y. Factors for effective BIM governance. J. Build. Eng. 2017, 10, 89-101. [CrossRef]

109. Ngowtanasawan, G. A causal model of BIM adoption in the Thai architectural and engineering design industry. In International High-Performance Built Environment Conference-A Sustainable Built Environment Conference 2016 Series; Ding, L., Fiorito, F., Osmond, P., Eds.; Elsevier Science Bv: Amsterdam, The Netherlands, 2017; Volume 180, pp. 793-803.

110. Hatem, W.A.; Abd, A.M.; Abbas, N.N. Motivation Factors for Adopting Building Information Modeling (BIM) in Iraq. Eng. Technol. Appl. Sci. Res. 2018, 8, 2668-2672. [CrossRef]

111. Hatem, W.A.; Abd, A.M.; Abbas, N.N. Barriers of Adoption Building Information Modeling (BIM) in Construction Projects of Iraq. Eng. J. Thail. 2018, 22, 59-81. [CrossRef]

112. Chan, D.W.M.; Olawumi, T.O.; Ho, A.M.L. Perceived benefits of and barriers to Building Information Modelling (BIM) implementation in construction: The case of Hong Kong. J. Build. Eng. 2019, 25, 10. [CrossRef]

113. Ahuja, R.; Sawhney, A.; Jain, M.; Arif, M.; Rakshit, S. Factors influencing BIM adoption in emerging markets-The case of India. Int. J. Constr. Manag. 2020, 20, 65-76. [CrossRef]

114. Statista Research Department. Market Value of the Construction Industry in China from 2018 to 2021. Available online: https:/ / www.statista.com/statistics/1068161/china-construction-industry-value/ (accessed on 18 February 2021).

115. Dodge Data \& Analytics. The Business Value of BIM in China. Available online: https://damassets.autodesk.net/content/dam/ autodesk/www/solutions/building-information-modeling/bim-value/EN_Business_Value_of_BIM_In_China_SMR_(2015 )FINALf.pdf (accessed on 31 January 2021). 